\title{
Inhibition of Cyclooxygenase Contracts Chicken Ductus Arteriosus
}

\author{
Toru Akaike and Susumu Minamisawa
}

\section{Keywords}

Ductus arteriosus $\cdot$ Prostaglandin $\cdot$ Chicken

Ductus arteriosus (DA) is an essential fetal artery that connects the main pulmonary artery and the descending aorta. Mammalian DA closes right after birth through vasoconstriction via a decrease in circulating prostaglandin $\mathrm{E}_{2}\left(\mathrm{PGE}_{2}\right)$ [1]. Avian DA also closes after birth although avians have no placenta that is a source of $\mathrm{PGE}_{2}$ in mammals. Previous studies have demonstrated that the $\mathrm{PGE}_{2}$ signal pathway is not involved in the constriction of isolated chicken DA [2]. However, the in vivo effect of $\mathrm{PGE}_{2}$ in avian DA has been little investigated.

We first measured blood concentration of $\mathrm{PGE}_{2}$ in chicken at embryonic day 19 (just before hatching) by enzyme immunoassay to confirm whether $\mathrm{PGE}_{2}$ circulated in the chicken blood during a perinatal period. Plasma $\mathrm{PGE}_{2}$ was significantly high in chicken compared to rat. $\mathrm{PGE}_{2}$ was strongly produced in chicken DA compared to chicken aorta and rat DA. Next, we determined the expression of prostaglandin E receptors (EP1, EP2, EP3 and EP4) in chicken DA. EP2 and EP3 receptors in fetal chicken DA were significantly higher than that of fetal chicken aorta. Especially, the EP2 receptor was significantly up-regulated before hatching and down-regulated after hatching. Finally, we performed a rapid whole-body freezing method to evaluate DA closure in vivo. We measured the internal diameter of DA two hours after in ovo injection of indomethacin, which is a non-selective cyclooxygenase inhibitor. Indomethacin constricted chicken DA at embryonic day 19 but did not constrict chicken aorta. These data suggest that, similar to mammals, $\mathrm{PGE}_{2}$ acts as a vasodilative factor on DA closure in avians.

T. Akaike $\cdot$ S. Minamisawa $(\bowtie)$

Department of Cell Physiology, The Jikei University School of Medicine,

Minato, Tokyo, Japan

e-mail: sminamis@jikei.ac.jp 
We demonstrated that factors of the $\mathrm{PGE}_{2}$ signal were detected in chicken DA and inhibition of cyclooxygenase contracted chicken DA. We concluded that the $\mathrm{PGE}_{2}$ signal may play an important role in acute vasodilatation of chicken DA closure.

Acknowledgment This work was supported by grants from the Ministry of Education, Culture, Sports, Science and Technology of Japan (T.A., S.M.), MEXT-Supported Program for the Strategic Research Foundation at Private Universities (S.M.), the Vehicle Racing Commemorative Foundation (S.M.), The Jikei University Graduate Research Fund (S.M.), and the Miyata Cardiology Research Promotion Foundation (S.M.).

\section{References}

1. Yokoyama U, Minamisawa S, Ishikawa Y. Regulation of vascular tone and remodeling of the ductus arteriosus. J Smooth Muscle Res. 2010;46:77-87.

2. Agren P, van der Sterren S, Cogolludo AL, et al. Developmental changes in the effects of prostaglandin E2 in the chicken ductus arteriosus. J Comp Physiol B. 2009;179(2):133-43.

Open Access This chapter is licensed under the terms of the Creative Commons Attribution 4.0 International License (http://creativecommons.org/licenses/by/4.0/), which permits use, sharing, adaptation, distribution and reproduction in any medium or format, as long as you give appropriate credit to the original author(s) and the source, provide a link to the Creative Commons license and indicate if changes were made.

The images or other third party material in this chapter are included in the chapter's Creative Commons license, unless indicated otherwise in a credit line to the material. If material is not included in the chapter's Creative Commons license and your intended use is not permitted by statutory regulation or exceeds the permitted use, you will need to obtain permission directly from the copyright holder.

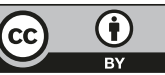

